\title{
Shareholder activism and the role of marketing: a framework for analyzing and managing investor relations
}

Citation for published version (APA):

Hoffmann, A. O. I., \& Pennings, J. M. E. (2008). Shareholder activism and the role of marketing: a framework for analyzing and managing investor relations. METEOR, Maastricht University School of Business and Economics. METEOR Research Memorandum No. 007 https://doi.org/10.26481/umamet.2008007

Document status and date:

Published: 01/01/2008

DOI:

10.26481/umamet.2008007

Document Version:

Publisher's PDF, also known as Version of record

Please check the document version of this publication:

- A submitted manuscript is the version of the article upon submission and before peer-review. There can be important differences between the submitted version and the official published version of record. People interested in the research are advised to contact the author for the final version of the publication, or visit the DOI to the publisher's website.

- The final author version and the galley proof are versions of the publication after peer review.

- The final published version features the final layout of the paper including the volume, issue and page numbers.

Link to publication

\footnotetext{
General rights rights.

- You may freely distribute the URL identifying the publication in the public portal. please follow below link for the End User Agreement:

www.umlib.nl/taverne-license

Take down policy

If you believe that this document breaches copyright please contact us at:

repository@maastrichtuniversity.nl

providing details and we will investigate your claim.
}

Copyright and moral rights for the publications made accessible in the public portal are retained by the authors and/or other copyright owners and it is a condition of accessing publications that users recognise and abide by the legal requirements associated with these

- Users may download and print one copy of any publication from the public portal for the purpose of private study or research.

- You may not further distribute the material or use it for any profit-making activity or commercial gain

If the publication is distributed under the terms of Article $25 \mathrm{fa}$ of the Dutch Copyright Act, indicated by the "Taverne" license above, 
Arvid O.I. Hoffmann, Joost M.E. Pennings

Shareholder Activism and the Role of Marketing: A Framework for Analyzing and Managing Investor Relations

$\mathrm{RM} / 08 / 007$

JEL code: M31, G1, G3

\section{METEबrR}

Maastricht research school of Economics of TEchnology and ORganizations

Universiteit Maastricht

Faculty of Economics and Business Administration P.O. Box 616

NL - 6200 MD Maastricht

phone : ++31433883830

fax : ++31433884873 
Arvid O. I. Hoffmann and Joost M. E. Pennings ${ }^{1}$

Shareholder Activism and the Role of Marketing: A Framework for Analyzing and Managing

\author{
Investor Relations
}

\footnotetext{
${ }^{1}$ Dr. Arvid O. I. Hoffmann is Assistant Professor of Finance at Maastricht University, P. O. Box 616, 6200 MD Maastricht, The Netherlands, telephone: +31 433884 602, fax: +31 4338 84 875, Email:

a.hoffmann@finance.unimaas.nl.

Prof. Dr. Ir. Joost M. E. Pennings is the ALEX Investment Bank Professor in Finance and Professor of Marketing at Maastricht University, P. O. Box 616, 6200 MD Maastricht, The Netherlands, a Professor in the Marketing \& Decision Sciences Group of the Office for Futures \& Options Research at the University of Illinois at UrbanaChampaign, and the AST Professor of Marketing at Wageningen University in the Netherlands, telephone +314338 83 934, fax: +31 433884 875, Email: joost.pennings@ finance.unimaas.nl and jme.pennings@mw.unimaas.nl.
} 
Shareholder Activism and the Role of Marketing: A Framework for Analyzing and Managing Investor Relations

\begin{abstract}
This paper proposes a conceptual framework that shows the role of (the) marketing (function) in managing investor relations. The framework complements existing literature on the marketingfinance interface and explicitly includes investor relationships as market-based assets. The framework provides (the) marketing (function) with tools to analyze and manage investor relations in order to improve companies' market performance and increase shareholder value by lowering the costs of shareholder activism. Three real-life scenarios of shareholder activism demonstrate the implications of the framework for marketing practice.
\end{abstract}


Introduction

"Upheaval at VNU is yet another example of increasing shareholder activism in Europe." (The Economist April $6^{\text {th }}$ 2006)

"Activist shareholders are getting tough with boards and managers." (The Economist May $31^{\text {st }}$ 2007)

"Keeping shareholders in their place: Bosses around the world celebrate a series of victories over activist shareholders." (The Economist October $11^{\text {th }}$ 2007)

“More activist investors are invited on to boards." (The Wall Street Journal April $7^{\text {th }} 2008$ )

As the quotes above illustrate, shareholder activism is rapidly gaining ground, sometimes making life uncomfortable for company boards and managers. The dimension of this problem is perhaps best illustrated by the recent outbreaks of shareholder activism both in the U.S. (see e.g., Verizon, Blockbuster, Hewlett-Packard, Disney, McGraw-Hill, and Motorola) as well as in Europe (see e.g., ABN AMRO, VNU, Stork, Ahold, and UBS) in which activist shareholders sometimes force companies to break up their businesses in their quest for shareholder value. As a result board meetings get dominated by issues of shareholder value, the role of finance, and the importance of investor relations. The rapid diffusion of investor relations departments among U.S. firms further support this notion (Rao and Sivakumar 1999). Yet, in a time in which investor relations is considered of strategic importance (Dolphin 2004), the role of (the) 
marketing (function) diminishes as illustrated by for example its decreasing influence at the level of corporate strategy (Nath and Mahajan 2008, p. 65). Webster (2005, p. 5) notes that marketing has been downsized or eliminated as a corporate function in many firms. Recent studies furthermore indicate that only about $50 \%$ of all Fortune 1000 firms have a Chief Marketing Officer (CMO) (Hyde, Landry, and Tipping 2004), while over $80 \%$ of all Fortune 500 firms have a Chief Financial Officer (CFO) (Zorn 2004). Moorman and Rust (1999, p. 180) point to the fact that although marketing in general may gain increasing prominence as a set of processes that all corporate functions participate in deploying, the specific contributions of the marketing function is a critical issue as its role may become more and more diffused. Other authors also point to the recent challenges of (the) marketing (function). Raju (2005, p. 17) for example stresses the relatively short life span of CMO's and the believe by many of them that one of their more serious challenges is justifying their own existence. As a general conclusion, Webster, Malter, and Ganesan (2003) claim that marketing professionals no longer have a "seat at the table".

There may be various reasons why marketing no longer has a seat at the table. This paper focuses on the (current) role of (the) marketing (function) in managing investor relations as one plausible explanation of the recent demise of marketing. In fact, although marketing recognizes the importance of shareholder value (Day and Fahey 1988) and expands its stakeholders to explicitly include investors (Srivastava, Shervani, and Fahey 1998, p. 2), recent literature on the marketing-finance interface does not explicitly deal with the actual relationship between a company and its investors. As a result, marketing leaves the management of investor relations to companies' investor relations departments. This is unfortunate as the marketing literature offers many valuable insights that are useful for managing investor relations. The current literature on 
investor relations ignores the role of marketing and focuses on communication (Dolphin 2004; Marston and Straker 2001). Although (the) communication (of financial information) is a necessary condition for managing investor relations, it is not a sufficient condition considering the dynamic nature and multidimensionality of these relations (cf. Pennings 2004). The authors propose that to successfully analyze and manage investor relations, the existing investor relations literature needs to be completed with insights from the marketing literature. We show how the relationship between a company and its shareholders may be analyzed and managed from a stakeholders and relationship marketing perspective. This paper complements existing literature on the marketing-finance interface and investor relations by specifically and explicitly focusing on the (different dimensions of the) relationship between a company and its shareholders.

The objective of this paper is to provide a conceptual framework that shows the role of (the) marketing (function) in managing the relationship between a company and its shareholders. This framework provides (the) marketing (function) with tools to analyze and manage investor relations in order to improve companies' market performance and increase shareholder value. The recent surge in shareholder activism illustrates the increasing importance of investor relations. When (the) marketing (function) is able to play a role in managing such relations, it can recoup its seat at the board of directors.

The remainder of this paper is organized as follows. First, we discuss the concept of shareholder activism and identify different types of shareholder activism. Second, we outline the current position of marketing in the shareholder activism and value debate. Third, we show how recent insights from the stakeholder literature and the literature on relationship marketing complement existing literature on investor relations. Fourth, we present a conceptual framework to analyze and manage investor relations from a marketing perspective and show how this 
framework extends existing frameworks. Fourth, we outline the implications of the framework for marketers by discussing three real-life scenarios of the relationship between a company and its investors. Moreover, we show how marketing can help companies' boards to turn investor relations into market-based assets. Finally, we discuss the conceptual framework and propose avenues for future research.

\section{Shareholder Activism and Shareholder Value}

The root of the current shareholder activism debate lies in the separation of ownership and control as is common to most modern publicly traded companies (Gillan and Starks 1998). By adopting the corporate form, the owners of the firm and the management of the firm are no longer necessarily united in the same person. This opens up the possibility of conflicts of interest, or agency problems between shareholders, the board of directors, and corporate management (Jensen and Meckling 1976). The existence of agency conflicts is well-documented in the corporate finance literature and has been used to explain choices of capital structure, dividend policy, maturity structure, and executive compensation (Albuquerue and Neng 2008; Ang, Cole, and Lin 2000; Dewenter and Warther 1998; Leland 1998). Agency conflicts are also important to understand shareholder activism (Gillan and Starks 1998). Shareholders - as owners of the firm - have a number of rights, including the right to appoint a board of directors. The board of directors, as agents of the shareholders, has the direct responsibility to monitor the performance of corporate management. The potential for shareholder activism arises whenever shareholders - erroneously or not - believe that the board of directors fails in its duty. That is, the shareholders are dissatisfied with the performance of the board and presumably the 
performance of the firm. In these circumstances, shareholders have three (main) options: sell their shares, i.e. "vote with their feet", hold their shares and voice their dissatisfaction, or hold their shares and do nothing. These three options have been called exit, voice, and loyalty (Hirschman 1971).

Shareholder activism represents a continuum of responses to corporate performance (Gillan and Starks 1998). At one side of this continuum, individuals buying and selling shares can already be considered to be "active" shareholders. By virtue of their initial purchase and subsequent change in ownership, they are actively participating and expressing their opinions of the corporation's performance. At the other side of the continuum, the market for corporate control (Jensen and Ruback 1983) also reflects "active" shareholders. In this case, shareholders buy into a firm through e.g., (hostile) takeovers and subsequently force the corporation to make fundamental changes in its structure. As an intermediate case, activist shareholders can buy a minority control in a firm with the intent of influencing the decision-making processes.

The most common definition of a shareholder activist is an investor who tries to change the status quo through the option "voice" without initiating a change in control of the firm (Gillan and Starks 1998, p. 3). However, as described in the introduction, shareholder activism can go hand in hand with changes in control of the firm. In this paper, we define shareholder activism as: all activities by shareholders to change the status quo either trough voice or changes in control. Note that the changes shareholders propose may refer to any aspect of the company's activities and the company structure, and the activities shareholders initiate may be either of a cooperative or an aggressive nature. Moreover, these changes may not only consider issues directly related to shareholder value (e.g., dividends or earnings prospects), but shareholders may also undertake activities with regard to social and societal issues. Shareholders, 
for example, may disapprove of the working conditions at a company's (foreign) plant or dislike the environmental perspective of a company and undertake activities to change this. Moreover, the changes that shareholders propose to management may be of a more or less drastic nature (e.g., closing down a foreign plant versus reducing company waste).

In Table 1 we propose three different types of shareholder activism, which we classify according to insights gained from the organizational literature. This literature distinguishes between operational, tactical, and strategic decision levels depending on e.g., the importance of an issue or decision for the organization as a whole (Eisenhardt and Zbaracki 1992; Kriger and Barnes 1992; Mintzberg 1979; Shapira 2002). In accordance with this literature, we classify the different types of shareholder activism as operational, tactical, and strategic shareholder activism. In Table 1 we give practical examples of the changes that shareholders may propose in each of these cases, indicate how drastic or far-reaching the proposed changes are, show whether the changes that shareholders propose are mainly enforced using voice versus control, and provide real-life examples of companies where this specific type of shareholder activism has occurred in the recent past.

$<$ Insert Table 1 about here $>>$

The Position of Marketing in the Shareholder Activism and Value Debate Traditionally, marketing has been defined as "the performance of business activities directed toward, and incident to, the flow of goods and services from producer to consumer or user" (American Marketing Association 1948, p. 210). For a considerable period of time, this definition of marketing has remained operational and the main toolbox of marketing consisted of the marketing mix or 4 P's (product, price, place, and promotion) (see e.g., Borden 1964). In line 
with this product-to-consumer focus, marketing metrics focused on sales volume, market share, or customer satisfaction and retention rates, and the most important stakeholder of marketing consisted of a firm's consumers and potential consumers. Although the consumer is still of utmost importance for marketing and the previously mentioned marketing metrics remain useful for a variety of purposes, marketing is now much broader defined. Today, marketing is seen as "the activity, set of institutions, and processes for creating, communicating, delivering, and exchanging offerings that have value for customers, clients, partners, and society at large"(American Marketing Association 2007). In addition, the recent surge of shareholder activism and corporations' concurrent focus on shareholder value introduces important changes for (the) marketing (function). Most notably, in recent years marketing has started to recognize that its ultimate purpose is to contribute to the enhancement of shareholder value (Day and Fahey 1988) and the stakeholders of marketing have been expanded to explicitly include a firm's existing as well as potential shareholders (Srivastava, Shervani, and Fahey 1998, p. 2). Moreover, there is increasing recognition in marketing that the field must become more financially accountable and should be able to indicate how its actions affect bottom line profit as well as shareholder value (Lehmann 2004; Rao and Bharadwaj 2008; Rust, Zahorik, and Keiningham 1995; Srivastava, Shervani, and Fahey 1997). As a result of these developments, a new stream of literature evolved, dealing with the marketing-finance interface.

Recently, for example, there have been studies on the impact of new product introductions on the market value of firms (Chaney, Devinney, and Winer 1991), the return on marketing (Rust, Lemon, and Zeithaml 2004), the relationship between customer lifetime value and shareholder value (Lehmann et al. 2006; Lehmann and Gupta 2006), the impact of marketing on firm value (Srinivasan and Hanssens 2007), as well as the relation between advertising 
spending, product innovations and stock returns (Joshi and Hanssens 2007; Joshi and Hanssens 2008; Srinivasan et al. 2007). Moreover, conceptual frameworks describing the marketingfinance interface have been developed, the most notable being the framework by Srivastava, Shervani, and Fahey (1998). The latter authors propose that marketing is concerned with the task of developing and managing market-based assets. Market-based assets are assets that arise from the commingling of the firm with entities in its external environment. Examples of market-based assets include customer relationships, channel relationships, and partner relationships. These market-based assets, subsequently, increase shareholder value by accelerating and enhancing cash flows, lowering the volatility and vulnerability of cash flows, and increasing the residual value of cash flows (Srivastava, Shervani, and Fahey 1998, p. 2). In their framework, Srivastava, Shervani, and Fahey explain how market-based assets lead to market performance and consequently shareholder value. More specifically, Srivastava, Shervani, and Fahey explain how customer and partner relationships through e.g., faster market penetration, price/share premiums, extensions, lower sales/service costs and increases in loyalty/retention lead to increases in shareholder value. Srivastava, Shervani, and Fahey's framework links market-based assets to shareholder value and thereby makes the marketing-finance interface explicit. Here we extend their framework by examining the relationship between a company and its investors. Often, it is implicitly assumed that to maintain satisfying investor relationships, it is sufficient for marketing to increase shareholder value. Like every marketing or channel relationship, however, the relationship between a company and its investors is both dynamic and multidimensional (cf. Pennings 2004) and therefore needs to be analyzed and managed in a systematic way. By combining the existing literature on the marketing-finance interface with earlier insights gained from the stakeholder literature as well as the literature on relationship marketing we develop a 
conceptual framework for marketing to systematically analyze and manage investor relations. This will subsequently provide marketing with a stronger position in the firm as it makes itself indispensable for managing investor relations and enables marketing to play a role in the current shareholder activism and value debate. To the best of our knowledge, there has been no research that explicitly and systematically addresses the role (the) marketing (function) could or should play in analyzing and managing investor relations. In the next section, we outline how the existing literature on stakeholders, relationship marketing, and investor relations can play a role in developing a conceptual framework that shows the relationship between a company and its shareholders and that (the) marketing (function) can use to analyze and manage investor relationships.

Stakeholders, Relationship Marketing, and Investor Relations

At a time that marketing recognizes that its ultimate goal is to contribute to shareholder value (Day and Fahey 1988), new organizational forms such as strategic partnerships and networks occur, leading to a changing role of marketing in the corporation (Webster 1992). For example, marketing focuses more and more on managing strategic partnerships and positioning the firm between vendors and consumers in the value chain with the overarching aim of delivering superior value to customers. Customer relationships are becoming the key strategic resource of business firms (Webster 1992). In accordance with this insight, marketing shifts away from focusing on one-time only transactions toward building long-term relationships with key customers, suppliers and other important stakeholders in a firm's internal and external environment. The latter is witnessed by the explosive growth in importance of relationship 
marketing both in business and academics (Srinivasan and Moorman 2005) as well as the insight that a truly effective implementation of the marketing concept(ion) requires corporations to embrace a stakeholder perspective (Polonsky, Schuppisser, and Beldona 2002). More specifically, it is found that building long-term relationships with customers in which true value is delivered leads to higher customer satisfaction, greater customer loyalty, and in turn growth, profit, and even more value (Reichheld 1996). Among other things, loyal customers lead to positive referrals, lower acquisition costs, lower operating costs, and higher revenues which may partly stem from the potential of obtaining a price premium from satisfied customers (Reichheld 1996).

Although the strategic partnerships as mentioned above may include investor relations and Reichheld (1996) points to the importance of targeting and keeping the right - that is, loyal investors, until recently the insights from relationship marketing have only infrequently been applied to the interactions that take place between a corporation and its investors. Rather, the recent literature that deals with investor relations neglects the role of marketing and is dominated by the role of communication (Dolphin 2004; Lovett and MacDonald 2005; Marston and Straker 2001). For example, Marston and Straker (2001) define investor relations as "the communication of information relating to the company to the financial community; analysts, investors and potential investors" (Marston and Straker 2001, p. 82). An early exemption to this myopic view on investor relations is the work by Tuominen (1997, p. 46) who suggests that "success in investor relations require companies to extend the scope of investor relations from a mere publication of obligatory and interim reports to more frequent, extensive, proactive, and diversified two-way interaction and communication". Inspired by findings from the Nordic School approach to services marketing (Berry and Parasuraman 1993; Fisk, Brown, and Bitner 
1993) and the interaction approach to industrial marketing (Glynn and Lehtinen 1995), Tuominen (1997, p. 47) develops the concept of "investor relationship marketing”. Investor relationship marketing is defined as "the continuous, planned, purposeful, and sustained management activity which identifies, establishes, maintains, and enhances mutually beneficial long-term relationships between the companies and their current and potential investors, and the investment experts serving them". Tuominen $(1997$, p. 50) in addition notes that committed investors may be willing to sacrifice short-term rewards because of the expectations of long-term benefits from their relationship with the company.

We propose that successfully analyzing and managing investor relations requires more than only communication. In the next section we therefore present a conceptual framework that characterizes the relationship between a company and its investors using five key dimensions that are rooted in the marketing literature. These dimensions - or relational factors - provide marketing with a toolbox to analyze and manage investor relations. That is, in addition to describing the nature of the relationship with investors, these factors may also serve as levers or motivators for companies to change the nature of this relationship (cf. Polonsky, Schuppisser, and Beldona 2002, p. 114).

\section{Conceptual Framework}

In Figure 1, we present the role of (the) marketing (function) in analyzing and managing the relationship between a company and its shareholders. Our conceptual framework extends the framework as proposed by Srivastava, Shervani and Fahey (1998) and explicitly includes investor relationships as market-based assets. Investor relationships are market-based assets if 
they lead to lower costs of shareholder activism and improve market performance. ${ }^{1}$ The conceptual framework shows several ways how managing investor relationships can contribute to shareholder value by improving market performance. More specifically, in this framework (the) marketing (function) has a responsibility to identify the possible mismatch between the desired state and the current state of the relationship that a company has with its shareholders. Based on a review of the existing literature on relationship marketing in general and the stakeholder perspective on marketing relationships in specific (Berman et al. 1999; Mitchell, Agle, and Wood 1997; Morgan and Hunt 1994; Polonsky, Schuppisser, and Beldona 2002; Reichheld 1996; Savage et al. 1991) we present five key dimensions - relational factors marketing can use to identify such mismatches (i.e. time horizon, risk attitude and risk perception, relationship orientation, trust, and commitment and reciprocity). Identifying possible mismatches is important, as they may be reason for shareholders to become active in order to try and change the status quo of their relationship with the company. As can be seen from Figure 1, shareholder activism may be costly and decrease market performance in four distinct ways. First, shareholder activism consumes management time as corporate management has to respond to activist shareholders' proposals for change. Second, when management dissociates itself from such proposals, it may be necessary to engage in legal actions to prevent the realization of the proposed changes. Moreover, in such situations it is often necessary to organize special shareholder meetings in which all shareholders can express their opinion about these proposals. Third, shareholder activism may necessitate strategic changes, for example withdrawing from or

\footnotetext{
${ }^{1}$ Because of their intangible, firm-specific nature, relational and intellectual market-based assets, such as investor relations, are often rare, difficult to imitate, without perfect substitutes, and of great value to a firm (Srivastava, Fahey, and Christensen 2001; Srivastava, Shervani, and Fahey 1998). These characteristics give these assets the potential to generate sustained competitive advantages (Barney 1991; Barney, Wright, and Ketchen 2001).
} 
entering certain markets or selling business activities. Such strategic changes may be costly. Fourth, companies that regularly experience shareholder activism may be considered to be less stable businesses and hence more risky investments (cf. Srivastava, Shervani, and Fahey 1998, p. 13). More risk leads to higher costs of capital, as shareholders demand a higher risk premium to hold the stock of such companies and lenders charge higher interest rates on their loans (Easley and O'Hara 2004; Mauer and Triantis 1994; Turnbull 1979). In line with the framework of Srivastava, Shervani and Fahey (1998), it is argued that such decreases in market performance may cause decreases in shareholder value either by lowering cash flows due to higher costs, increasing the vulnerability and volatility of these cash flows by frequent strategic changes, or reducing the net present value of these cash flows due to higher costs of capital. To prevent this, (the) marketing (function) can initiate actions to reduce possible mismatches between the desired state and the current state of the relationship between a company and its shareholders using the five relational factors as levers of change. This may attenuate shareholder activism and improve market performance. The five relational factors and the way (the) marketing (function) can use them to analyze and manage investor relationships are discussed in more detail.

\section{$<<$ Insert Figure 1 about here $>>$}

\section{Time Horizon}

The first relational factor to take into account when assessing and managing the relationship between a company and its investors is both parties' time horizon. It is important to take this factor into account, as it cannot be assumed that the time horizon of the company's management and the owners of the firm are always similar. The economics literature on intertemporal choice shows that people differ in time discounting and time preference, resulting in heterogeneity in 
people's time horizons (Frederick, Loewenstein, and O'Donoghue 2002; O'Donoghue and Rabin 1999). These findings suggest that there may be heterogeneity in time horizon between a company and its shareholders. If the time horizons differ too much, conflicts with regard to how the company should be run are likely to occur. For example, many companies shifted from a short-term, transactional perspective with regard to all of their customers towards building longterm relationships with their best customers. This requires a company to take a long-term perspective that allows the development of long-term profitable relationships with customers that may take some time to pay off. Most likely, the company will therefore evaluate the performance of (the) marketing (function) based on marketing metrics with a long-term focus, such as customer's life-time value, instead on short-term sales. In case the owners of these companies also support a long-term perspective with regard to their investment in this company, shareholder activism is unlikely. However, if investors are looking for more short-term growth in profits, this will make it difficult for the company to execute its strategy and may cause frustration on the side of investors. This frustration may subsequently result in shareholder activism as investors try to change the time horizon of the corporation for their own benefit. Over time, the time horizons of the company and its investors may move in opposite directions due to relationspecific reasons such as an ageing investor population (cf. Fisher and Statman 1999) or a major shift in corporate strategy. Based on the previous discussion, we propose:

\section{P1. The degree of time horizon congruency between companies and shareholders is negatively} related to shareholder activism.

Risk Attitude and Risk Perception 
The second relational factor addresses risk attitudes and risk perceptions of companies and their shareholders. ${ }^{1}$ Risk attitude and risk perception drive decision-makers' behavior (Pennings and Smidts 2000; Pennings and Wansink 2004; Pennings, Wansink, and Meulenberg 2002) and are important for understanding the dynamics of the relationship between a company and its shareholders. Risk may be perceived differently by a company and its shareholders and how these parties deal with perceived risk depends on their risk attitude (cf. Pennings and Wansink 2004). As a matter of fact, company managers and shareholders may have different "appetites" for risk (cf. Brisley 2006; Carpenter 2000), which is illustrated by the recent subprime crisis. More specifically, heterogeneity in risk attitude and risk perception between a company and its shareholders is reason for conflicts and may lead to shareholder activism.

Risk perception reflects a person's interpretation of the chance to be exposed to the content of the risk and is defined as someone's assessment of the uncertainty of the risk content inherent in a particular situation. Risk attitude reflects someone' general or consistent predisposition toward risk (Pennings and Wansink 2004, p. 699; Pennings, Wansink, and Meulenberg 2002, p. 93). We do not expect risk attitude and risk perception to individually have a direct impact on the dynamics of the relationship between a company and its shareholders. Rather, it is the combination of risk attitude and risk perception that influences behavior. After all, regardless of their risk attitudes companies and shareholders will not change their behavior if no risk is perceived in a certain situation. The interaction between risk attitude and risk perception (IRAP) represents how someone intends to cope with risks (Pennings and Wansink 2004). We define IRAP as positive when a company or a shareholder perceives risk and is risk

\footnotetext{
${ }^{1}$ The decision-making literature sometimes distinguishes between risk and uncertainty (Knight 1921). In that literature, the term risk refers to situations in which decision-makers know the probabilities associated with the possible consequences, while the term uncertainty refers to situations in which these probabilities are unknown. Consistent with the marketing literature, this paper uses the term risk to mean uncertainty (cf. Conchar et al. 2004; Cox 1967; Cox and Rich 1964).
} 
averse. We define it as negative when a company or a shareholder perceives risk and is risk seeking. We define it as neutral when a company or a shareholder either does not perceive any risk or is risk neutral (cf. Pennings and Wansink 2004, p. 700). Clearly, when a company has a negative IRAP and its shareholders have a positive IRAP, there is reason for conflicts and shareholder activism may abound. After all, in this situation it is likely that a company has a propensity to engage in relatively risky projects, while its shareholders are risk averse. To resolve this situation, shareholders may become active and force the company to engage in less risky projects. A similar situation may occur when a company has a positive IRAP and its shareholders have a negative IRAP. In addition, shareholders may not perceive the same level of risk as companies do because of asymmetry in information. Again, this may cause agency problems and lead to shareholder activism (cf. Albuquerue and Neng 2008; Jensen and Meckling 1976; Marston and Straker 2001). Hence we propose:

P2. The degree of IRAP congruency between companies and shareholders is negatively related to shareholder activism.

\section{Relationship Orientation}

The third relational factor concerns the relationship orientation. The relationship orientation guides the parties' behavior and responses in the relationship (Deutsch 1982; Hosseini and Brenner 1992; Polonsky, Schuppisser, and Beldona 2002), while at the same time the kind of behavior experienced by the parties also shapes their relationship orientation (Savage, Nix, Whitehead, and Blair 1991). The term relationship orientation is used here to refer to the motivational and evaluative orientation of the parties with respect to the relationship. 
We distinguish cooperative, individualistic, and competitive relationship orientations (Deutsch 1982). In case of a cooperative orientation, a party takes not only its own welfare, but also the welfare of the other party into consideration. When parties have an individualistic orientation, parties are only interested in doing as good as they can without being bothered by how well the other party is doing. With a competitive orientation, a party does not only seek to do as well as it can for itself but also actively tries to gain the upper hand in conflicts with the other party. The relationship orientation of a company and its investors may differ, which again may lead to conflicts of interest and shareholder activism. For example, a company guided by an individualistic orientation may treat investors solely as providers of working capital and ignore their other needs or concerns with respect to for example operating in an environmentally friendly way. This may lead investors to engage in shareholder activism to exercise their shareholder rights and change the current situation. On the other hand, when shareholders are guided by an individual or even a competitive orientation, they will fight solely for their own benefit and may actively try to gain the upper hand in conflicts with the company. This may happen if shareholders for example are not satisfied with the returns on their investment and subsequently - by engaging in shareholder activism - force a company to increase dividends or sell business activities. When both the company and the investors have a cooperative relationship orientation, we expect no conflicts of interest and there will be less or no reason for shareholder activism (ceteris paribus), as both parties' wellbeing is taken into consideration. Yet, as soon as either the company or the investor is guided by an individualistic or even a competitive relationship orientation, either the company will be frustrated in executing its business strategy or the shareholder will find a reason to engage in shareholder activism. Hence we propose: 
P3. The degree of relationship orientation congruency between companies and shareholders is negatively related to shareholder activism.

\section{Relationship Evaluation Mode}

During the course of a relationship, parties continuously evaluate their interactions. These evaluations can be attributed to either an operational or a strategic evaluation mode (Polonsky, Schuppisser, and Beldona 2002). An operative evaluation mode is used when parties are only concerned with evaluations of short-term cost-benefit or efficiency implications of past interactions instead of (future) opportunities. In contrast, the strategic evaluation mode focuses on long-term opportunities of the relationship, searches for strategic options facilitated by the relationship, and regards the relationship itself as a strategic resource and emphasizes the investment character of the relationship (Barney 1991; Hall 1993). Dependent on the relationship between a company and its investors in terms of the other relational factors, an operative or a strategic evaluation mode may be preferred. In all instances, however, to prevent conflicts and shareholder activism it is important that both a company and its investors evaluate a relationship using the same evaluative orientation. Imagine for example the tension that may occur when investors evaluate a relationship using an operative evaluation mode while the company uses a strategic evaluation mode or vice versa. In these situations, one party focuses on short-term costbenefit implications, while the other party searches for long-term opportunities of the relationship. Shareholders will be inclined to resolve this tension by engaging in shareholder activism. Based on the previous discussion, we propose: 


\section{P4. The degree of evaluation mode congruency between companies and shareholders is negatively related to shareholder activism.}

Trust

The fourth relational factor that we take into consideration is the trust between parties. This factor is widely discussed as an important factor in the literature on relationship marketing (see e.g., Moorman, Zaltman, and Deshpande 1992; Morgan and Hunt 1994) and is also a useful factor when analyzing the relationship between a company and its investors. Trust is the willingness of one party to be vulnerable to the actions of the other party (cf. Mayer, Davis, and Schoorman 1995). Distrust is the willingness of a party to avoid any vulnerability to the other party. It is possible to distinguish between three forms of trust that build on each other (Lewicki and Bunker 1995). The first form of trust is calculus-based trust. In this situation, "trust is an ongoing, market-oriented, economic calculation whose value is derived by comparing the outcomes resulting from creating and sustaining the relationship to the costs of maintaining or severing it" (Lewicki and Bunker 1995, p. 145). In relationships based on this type of trust, parties trust each other because they believe that to some extent they can control the costs and benefits of the other's actions, such that the other party is anxious to act consistently (Polonsky, Schuppisser, and Beldona 2002, p. 115). The second form of trust is knowledge-based trust that relies on information instead of some form of deterrence as is the case with calculus-based trust. This type of trust is possible in a relationship if parties have developed an intimate knowledge of each other, so that the other's behavior is predictable because it is known how the other will act in a specific situation. The third form of trust is identification-based trust which exists when the parties thoroughly understand, agree with and endorse each other's intentions and objectives. In 
this case, needs, choices, and preferences are mutually shared and each party can effectively act for the other (Polonsky, Schuppisser, and Beldona 2002). It is suggested that calculus-based trust is usually the first form of trust to develop in a relationship and is strengthened in a stepwise fashion as the number and the significance of the interactions increases (Lewicki and Bunker 1995). Breaches of trust may set back the relationship evolution one or more steps, whereby the higher forms of trust are more resilient to breaches of trust. Obviously, the extent to which the relationship between a company and its investors is regulated by either lower or higher forms of trust has an effect on the nature of that relationship. More specific, if calculus-based trust is dominant amongst a company's investors, this will make shareholder activism focused on shortterm outcomes more likely than when identification-based trust regulates this relationship. In the latter situation, it will be easier for companies and their investors to engage in more deliberate and long-term exchanges in which it is understood and accepted that sometimes one has to invest in a relationship before it is possible to reap the profits of this investment. Naturally, it also depends on how the relationship between a company and its investors scores on other relational factors to determine which form of trust is most suitable. For example, corporations that still advocate a transactional perspective with regard to their customer interactions may find a relationship with their investors based on calculus-based trust to be satisfactory. However, in this situation they have to be prepared to frequently deal with shareholder activism, as every time that shareholders suspect that the company may achieve more benefits than they do, they are anxious to restore this balance and may engage in shareholder activism. Therefore, even for such organizations a higher form of trust is preferable as a more intimate knowledge of a partner's objectives and possible actions reduces the chances for conflicts and subsequent shareholder activism. We therefore propose: 
P5. The adoption of higher forms of trust between companies and shareholders is negatively related to shareholder activism.

\section{Commitment and Reciprocity}

The fifth and last relational factor concerns commitment and reciprocity. Commitment is an essential ingredient of successful long-term relationships (Gundlach, Achrol, and Mentzer 1995). It has been defined as "an implicit or explicit pledge of relational continuity between exchange partners" (Dwyer, Schurr, and Oh 1987, p. 19). Most important for managing the relationship between a company and its investors, commitment implies a willingness to make short-term sacrifices to realize longer-term benefits (cf. Dwyer, Schurr, and Oh 1987). Commitment has also been associated with motivation and involvement (Mowday, Porter, and Steers 1982), positive effect and loyalty (Kanter 1972), and obedience to organizational policies (Angle and Perry 1981). Commitment is important to build long-term relationships between companies and investors and allow companies to engage in e.g., uncertain new product development projects with immediate costs, but uncertain and unknown future profit streams. Disproportionate commitment, however, establishes an incentive for less committed partners to act opportunistically (Gundlach, Achrol, and Mentzer 1995). For example, investors that are less committed to the company than the company is to them may engage in shareholder activism aimed at obtaining a disproportionate amount of benefits in comparison to what the company receives from the shareholder in return. It is therefore important that a company and its investors commit themselves to a similar extent to their relationship, or at least are aware of the before- 
described possibility of opportunistic behavior. Based on the previous, we develop the following proposition:

P6. The level of - and degree of congruency in - commitment between companies and shareholders is negatively related to shareholder activism.

Related to the previous proposition is the question what pattern of committing actions can be observed between partners. In other words, how do parties reciprocate their actions and/or commitments? Reciprocity also lies at the core of the relationship marketing literature (Bagozzi 1995). "Reciprocity specifies that one should repay help with help, or at least not repay help with harm (positive reciprocity); and/or that one should repay harm with harm or at least not repay harm with help (negative reciprocity or revenge)" (Meeker 1983, p. 22). Over time, the relationship between companies and investors may develop in different directions, depending on whether action patterns develop based on positive or negative reciprocity. Moreover, the strength of reciprocity may differ between different relations and/or change over time. Strong-form reciprocity leads parties' interactions to take the form of equivalent and synchronized "quid pro quo" exchanges, ensuring that the parties are even at every point in time (Polonsky, Schuppisser, and Beldona 2002). Strong-form reciprocity is typical for a traditional transactional perspective on marketing interactions and in general does not allow parties to develop strategic initiatives that require trust of the other party or that take some time to pay off. Weak-form reciprocity may develop over time after parties have experienced that others will positively reciprocate own actions on a regular basis. Parties in this case allow longer times for reciprocation and do not try to meticulously balance their contribution-benefit accounts at every point in time (Polonsky, 
Schuppisser, and Beldona 2002). Weak-form reciprocity is typical for relationship-based marketing interactions and allows companies to develop more long-term strategic initiatives. We expect that weak-form reciprocity reduces shareholder activism, as investors trust the company enough to believe that e.g., short-term earnings decreases are either unavoidable or necessary for the long-term viability of the firm. Based on the previous discussion, we develop the following proposition:

P7. The mutual adoption of weaker forms of reciprocity between companies and shareholders is negatively related to shareholder activism.

In the next section, we show how the conceptual framework and accompanying propositions form a toolbox for (the) marketing (function) to analyze and manage the relationship between a company and its shareholders by discussing three real-life scenarios.

\section{Implications for Marketers}

Based on the relational factors of the conceptual framework and the previously identified types of shareholder activism, we present three specific scenarios with respect to the relationship between a company and its investors. These different scenarios may require different actions from (the) marketing (function). These actions may sometimes focus on communication, but may also be more drastic, like strategic share repurchase programs or management buyouts. More specifically, the relational factors as identified in the previous section may act as levers for 
companies to change the nature of their relationship with shareholders. In Table 2 below, we outline the scenarios and give practical examples for each of them.

$<$ Insert Table 2 about here $>>$

Scenario A - "say on pay" - describes a situation of shareholder activism that is typical for the recent interactions between Blockbuster and its shareholders. In Figure 2, the Blockbuster case is described in more detail.

In this scenario, shareholder activism mainly takes an operational form and is concerned with short-term issues like executive pay ("say on pay"). Investors perceive their investments in the company to be risky, while they are risk averse (positive IRAP). Considering their positive IRAP, investors are likely to propose actions intended to reduce the risk of their investment, like requesting large dividend payments or the replacement of CEO's with people they know and trust. Investors are mainly interested in their own benefits and are not interested in the benefits that accrue to the other party as they have an individual relationship orientation. Moreover, investors evaluate their relationship with the company using a short-term cost-benefit perspective. That is, they use an operative evaluation mode. Trust between company and investor is based on a calculation of the costs of maintaining or ending the relationship and is focused on financial issues. The commitment of shareholders to the company is low and investors want to be even with the company at every point in time, leading to a culture of "take what you can before the other party gets more". A disadvantage of this situation is that top management's attention to strategic issues dilutes and management has to spend time dealing with more operative matters and requests. As management time is costly, this reduces the firm's market performance. Moreover, investors only bring capital to the company and do not contribute in other ways through e.g., providing specific technological know-how, insight into foreign markets or 
specialized management skills. An advantage of this situation is that investors do not mingle in more strategic issues like what new products should be developed or markets to be entered, which reduces the costs of making frequent strategic changes. However, management's continuing need to deal with investors' short-term demands makes it difficult to develop and execute long-term plans.

In this scenario, the propositions related to the conceptual framework as presented in the previous section suggest the following marketing actions. First, (the) marketing (function) can analyze whether the time horizon of the activist shareholders is representative for the overall time horizon of the company's shareholders. In case the short-term focus is exclusive to (a small group of) activist shareholders and is not shared by the remaining shareholders, (the) marketing (function) can start a strategic share repurchase program in which shares from the activist shareholders are bought and reissued to others. In case the short-term focus is typical for all shareholders, (the) marketing (function) has a number of options for management to align the company's time horizon with that of its investors. For example, when shareholders focus on short-term issues while the company takes a long-term perspective, the company can communicate to the shareholders the detrimental effects of such a focus on future shareholder value. If this doesn't reduce or eliminate shareholder activism, a company may consider changing its time horizon to match that of the majority of its shareholders. As an ultimate solution, a company may consider going private. Second, considering their positive IRAP, investors are likely to propose actions that reduce the risk of their investment. Marketing can take actions to reduce the perceived risk of shareholders and attenuate information asymmetries by providing more (detailed) information about the company's projects and expected cash flows. Third, considering the dominant relationship orientation of this scenario, there is neither a mutual 
concern for each other's well-being nor do parties engage in an active dialogue to discuss each others interests. To overcome this deadlock, (the) marketing (function) can outline to company's management the advantages that a mutual adoption of a cooperative relationship orientation can bring. Fourth, (the) marketing (function) can take actions to ensure congruency in evaluation mode between the company and its shareholders. Although shareholders' short-term cost-benefit perspective in this scenario may have a number of disadvantages, such a perspective does not necessarily need to result in shareholder activism. Rather, the company and its shareholders should evaluate their relationship using a similar evaluation mode, which may be either operative or strategic. Fifth, a higher level of trust needs to be developed between the company and its shareholders by gaining more knowledge about and endorsing each other's intentions and objectives. Sixth, both parties are advised to demonstrate a higher commitment to this relationship and do so to a similar extent. This means that both the company and its shareholders must be willing to (incidentally) make short-term sacrifices to obtain long-term benefits. Marketing has a central role in explaining the relationship between short-term costs and longterm benefits and guiding parties towards higher commitment by organizing for example special sessions with shareholders. Seventh, all the previous actions ideally go hand in hand with adopting weak-form reciprocity, allowing more long-term strategic initiatives to be developed and executed.

\section{$<<$ Insert Figure 2 about here $>>$}

Scenario B - "break it and sell it" - describes a situation of shareholder activism that is typical for the recent interactions between ABN AMRO and its shareholders. In Figure 3, the ABN AMRO case is described in more detail. 
In this scenario, shareholder activism takes a strategic form and concerns issues with a short time horizon as well as issues with a long time horizon. Again, shareholders perceive their investments to be risky and engage in actions to reduce this risk (positive IRAP). Indeed, to "cash in" on their investments, investors may suggest breaking up a company and selling the constituent parts to the highest bidder. In this scenario, investors are mainly interested in their own benefits and are not concerned with the benefits that accrue to the other party. Also, in conflicts with the company, investors may actively try to gain the upper hand. That is, shareholders are guided by either an individual or a competitive relationship orientation. Although in this situation investors do recognize long-term opportunities and strategic options, they are overly concerned with short-term cost-benefit issues. In other words, shareholders evaluate their relationship with the company using a mixture of an operative and a strategic evaluation mode. The trust between the company and its investors is based on either a calculation of the costs of maintaining or ending the relationship or an intimate knowledge of how the other partner will react in a variety of situations. That is, the trust between parties is either calculus- or knowledge-based. Although the commitment of shareholders to the company in this situation may be of an intermediate level, investors want to be even with the company at every point in time as strong-form reciprocity is dominant. Issues at hand in this situation are of a more drastic nature and may include breaking up a company if shareholders belief that the stock market puts a negative value on the synergy of a company's constituent parts. However, in this situation shareholders may ignore the potential (long-term) advantages of a larger and more diversified company, such as cross-fertilization between different business units, the standing of the company in the marketplace as a full-line service provider, or the reduced volatility in cash flows as a result of being active in different product and/or country markets. 
In this scenario, the propositions related to the conceptual framework as presented in the previous section suggest the following marketing actions. First, companies need to align their time horizons to those of their shareholders. However, due to the strategic nature of the shareholder activism in this case, control is the dominant enforcement method of shareholders which may give companies a hard time trying to change shareholders' time horizon. Rather, shareholders may propose changes in control of the firm to force the company to adopt their time horizon. Assuming that the activist shareholders have a controlling stake, (the) marketing (function) can assist company boards to use arguments - voice - to convince shareholders to adopt the company's time horizon. As an alternative, (the) marketing (function) can initiate actions to buy back activist investors' shares. The complexity of the situation is increased by the fact that shareholders switch between a short time horizon and a long time horizon dependent on the issue at hand. This means that shareholders may e.g., want both a higher dividend this year and a sell-off of some business activities in five years. It is marketing's function to inform company's management about this complexity and develop strategies to deal with it. Second, considering the positive IRAP of the shareholders, investors will go to great lengths to reduce the risk of their investment. As in scenario A, (the) marketing (function) can convince management to provide shareholders with more information to align the risk perception of the company and its shareholders. This may prevent shareholders to perceive the company's projects as unduly risky. Third, in the ideal situation, both the company and its shareholders adopt a cooperative relationship orientation. That is, the company and its shareholders express a concern for each other's well-being and act in a way that reflects this concern. However, considering that the dominant relationship orientation in this case varies between an individualistic and a competitive orientation, it may be very difficult for marketing to change the relationship orientation. The role 
of (the) marketing (function) is to persuade shareholders that a cooperative relationship orientation may actually result in a higher overall level of benefits from which both parties may gain. Fourth, shareholders use a combination of an operative and a strategic evaluation mode. It would be better if both parties use the same evaluation mode. Moreover, as the operative evaluation mode focuses on short-term cost-benefit issues, while the strategic evaluation mode focuses on a relationship's long-term strategic benefits, (the) marketing (function) should stress the advantages of both parties adopting a strategic evaluation mode. Fifth, a higher level of trust between the company and its shareholders is advised. Marketing should stimulate management to gain more knowledge about the intentions and objectives of the company's shareholders. Moreover, (the) marketing (function) can communicate the company's true intentions and objectives to shareholders and initiate actions to increase shareholders' commitment to these objectives. Doing so may lead to the conclusion that the actual objectives of both parties require less drastic and costly changes than breaking up the company. Sixth, marketing can start actions that stimulate both parties to commit to a higher extent to this relationship and do so to a similar extent, like organizing special meetings between companies' management and shareholders. A higher commitment may help shareholders to agree to undertaking less drastic actions to improve the performance of the firm, as they may accept and believe that making short-term earnings sacrifices leads to a better and more sustainable long-term performance. Seventh, marketing's actions should lead to the mutual adoption of weak-form reciprocity, providing room for developing and executing long-term strategic initiatives leading to a sustainable long-term performance.

$<<$ Insert Figure 3 about here >> 
Scenario C - "together achieve growth" - describes a situation of shareholder activism that is typical for the interactions between Toyota and its shareholders. In Figure 4, the Toyota case is described in more detail.

In this scenario, shareholder activism may be of an operational, tactical, or strategic nature, but always takes a long-term perspective. Investors do not find the company particularly risky and have a neutral IRAP. Moreover, investors are truly interested in both their own benefit and the benefit of the company as they believe that when the company is doing well, they also will do well. That is, a cooperative relationship orientation is dominant. Investors evaluate their relationship with the company focusing on long-term opportunities and actively search for strategic options to help the company forward. In other words, a strategic evaluation mode is used. Both parties thoroughly understand, agree with and endorse each other's intentions and objectives as there is identification-based trust between the company and its investors. The commitment of shareholders to the company is high and investors know that the company will positively reciprocate their own actions on a regular basis eliminating the need to be even at every point in time. We could state that this scenario is a true example of "positive shareholder activism" in which shareholders and companies engage in interactions that are mutually rewarding and help each other to achieve their goals. Investors may contribute technological know-how or strategic insights besides their capital, while the company delivers a steady stream of (increasing) profits to shareholders. In this scenario, the relationship between a company and its shareholders is in line with the previously presented propositions and constitutes a typical best practice case. However, mismatches may develop over time. Therefore, (the) marketing (function) should continually assess the relationship between the company and its shareholders using the five relational factors and take appropriate actions whenever mismatches do occur. 
$<<$ Insert Figure 4 about here $>>$

In Figure 5 we summarize the implications for marketers by developing seven rules for managing investor relations.

< Insert Figure 5 about here $>>$

Discussion

This paper offers (the) marketing (function) a toolbox that can be used to analyze and manage investor relations. This may help marketing to recoup its seat at the board of directors, as it provides marketing with a role in the current shareholder activism debate. The toolbox consists of five relational factors that can be used to characterize the relationship between a company and its investors and that may act as levers of change. These five relational factors are part of a wider conceptual framework that describes the role of (the) marketing (function) for analyzing and managing investor relations and extends the earlier proposed framework of Srivastava, Shervani, and Fahey (1998). The extended framework treats investor relationships as market-based assets. Managing these market-based assets reduces shareholder activism, leads to better market performance and subsequently increases shareholder value.

Adopting the proposed framework has important consequences for marketers and the role of (the) marketing (function). Marketing will increasingly become a boundary spanning function as it engages in analyzing and managing investor relations. That is, marketing takes over part of the traditional responsibilities of the investor relations department. However, there is a clear-cut distinction between the focus and actions of (the) marketing (function) and traditional investor relations when analyzing and managing investor relations. That is, while traditional investor 
relations is static, focuses on the status-quo, and communicates obligatory financial information, the role of (the) marketing (function) is dynamic, forward-looking, and goes beyond communication. More specifically, traditional investor relations focuses on the current (information) needs of a company's current investor population, but does not question the appropriateness of the current investor population given the company's long-term strategic vision. In contrast, (the) marketing (function) may find that the current investor population hinders the company in executing its long-term strategy or, more generally, find mismatches in the current relationship between a company and its shareholders large enough to advise companies' boards to change the composition of the current investor population. Indeed, as stated by Srivastava, Shervani, and Fahey (1998, p. 15), "the market-based assets an organization possesses may not be those it needs". Finally, (the) marketing (function) acknowledges and acts upon heterogeneity across and between companies and shareholders in terms of time horizon, risk attitude and risk perception, relationship orientation, relationship evaluation mode, trust, and commitment and reciprocity.

Future research needs to (empirically) examine the possible interactions between the different relational factors that guide the relationship between companies and shareholders. For example, parties' time horizon and trust interact in the sense that if parties do not trust each other, it will be very difficult to adopt a long time horizon. Moreover, the different forms of reciprocity that parties adopt and the extent to which parties trust each other are likely to interact. That is, without a basic level of trust, it is unlikely that parties will ever engage in weak-form reciprocity, as they are not sure enough that over time the other party will positively reciprocate their actions. Finally, the interaction between parties' time horizons, risk attitudes, and risk perceptions deserves the attention of marketing scholars. For example, if risk is operationalized 
as the probability of a loss, risky investments become less risky with longer investment time horizons (Klos, Weber, and Weber 2005). Moreover, behavioral finance literature suggests that investors have different risk tolerances or risk "appetites" connected to different time horizons, and associated with different parts of their investment portfolios (Shefrin and Statman 2000; Statman 1999; Thaler 1985; Thaler 2000). Instead of optimizing the overall risk-return relationship of their portfolio, investors bracket choices to narrow (Read, Loewenstein, and Rabin 1999), which is often suboptimal (Pennings et al. 2008). Future work may show the effect of these interactions on the (dynamical nature of the) relationship between companies and investors.

Finally, future research may explore how marketing's increasing concern for shareholder value and investor relations affects the dominant logic of marketing (cf. Vargo and Lusch 2004; Vargo and Lusch 2008). Expanding the stakeholders of marketing to explicitly include shareholders (Srivastava, Shervani, and Fahey 1998, p. 2) and an active role of marketing in managing investor relations suggests that marketing's logic and role may increasingly center around managing external relations, such as investor relations. 
Table 1

Three Types of Shareholder Activism

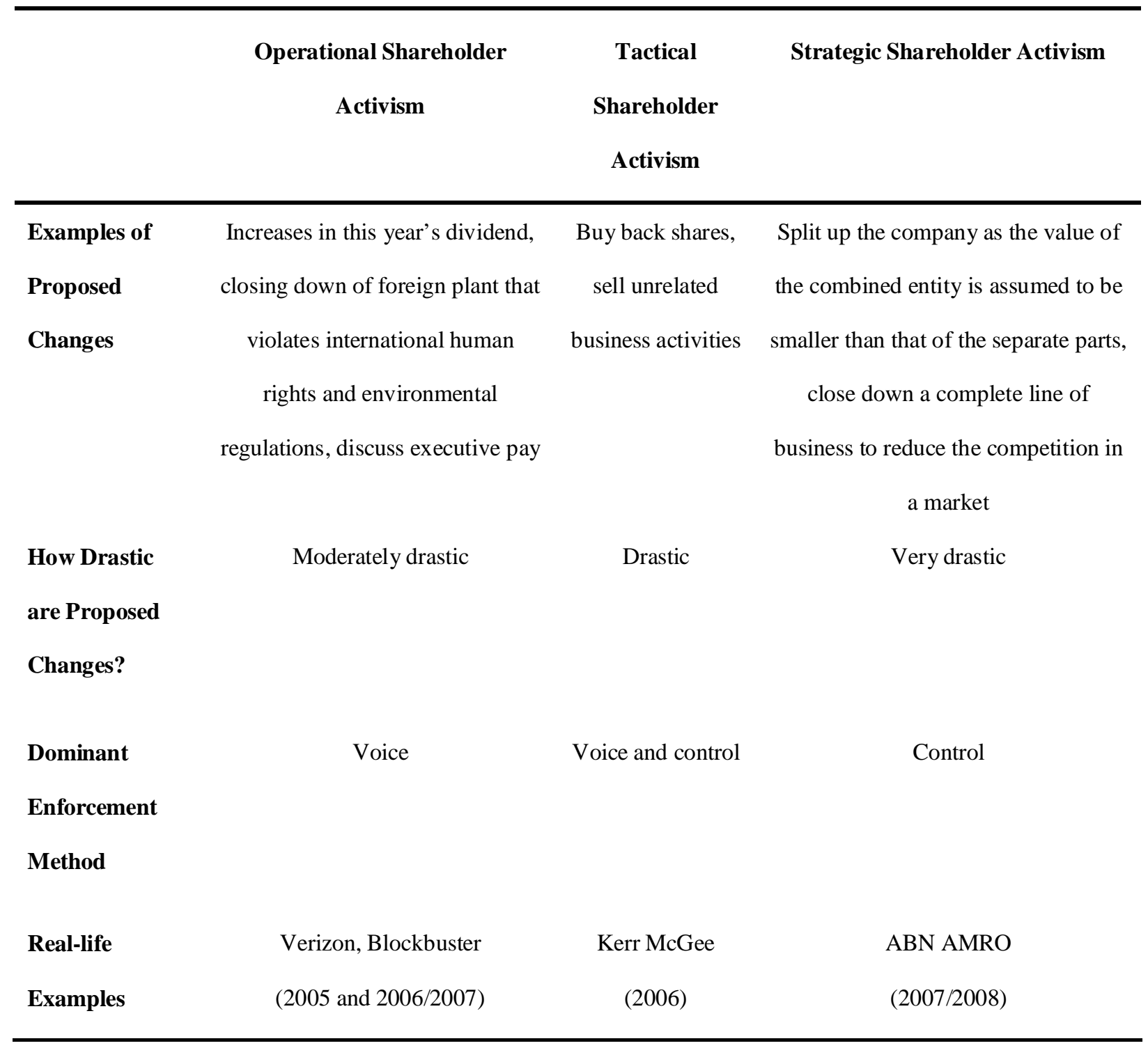


Table 2

Three Scenario's of the Relationship between a Company and its Shareholders

\begin{tabular}{|c|c|c|c|}
\hline & $\begin{array}{l}\text { Scenario A: } \\
\text { "Say on pay" }\end{array}$ & $\begin{array}{l}\text { Scenario B: } \\
\text { "Break it and sell it" }\end{array}$ & $\begin{array}{c}\text { Scenario C: } \\
\text { “Together achieve growth" }\end{array}$ \\
\hline Issues & $\begin{array}{c}\text { Executive } \\
\text { compensation/dividend } \\
\text { s/composition of board } \\
\text { of directors }\end{array}$ & $\begin{array}{l}\text { Value of sum smaller than } \\
\text { parts, sell off business } \\
\text { activities to highest bidder }\end{array}$ & $\begin{array}{l}\text { Mutual help to develop and } \\
\text { deliver superior products, } \\
\text { excellent customer value, and } \\
\text { long-term shareholder value }\end{array}$ \\
\hline Real-life example & $\begin{array}{l}\text { Blockbuster } \\
(2006 / 2007)\end{array}$ & $\begin{array}{l}\text { ABN AMRO } \\
(2007 / 2008)\end{array}$ & $\begin{array}{c}\text { Toyota } \\
(1937-2008)\end{array}$ \\
\hline $\begin{array}{l}\text { Dominant type of } \\
\text { shareholder activism }\end{array}$ & Operational & Strategic & Operational/Tactical/Strategic \\
\hline Dominant time horizon & Short-term & Short-term and Long-term & Long-term \\
\hline IRAP & Positive & Positive & Neutral \\
\hline $\begin{array}{l}\text { Dominant relationship } \\
\text { orientation }\end{array}$ & Individual & Individual/Competitive & Cooperative \\
\hline $\begin{array}{l}\text { Dominant evaluation } \\
\text { mode }\end{array}$ & Operative & Operative/Strategic & Strategic \\
\hline Dominant form of trust & Calculus-based & $\begin{array}{c}\text { Calculus/Knowledge- } \\
\text { based }\end{array}$ & Identification-based \\
\hline $\begin{array}{l}\text { Average level of } \\
\text { commitment }\end{array}$ & Low & Low/Intermediate & High \\
\hline $\begin{array}{l}\text { Dominant form of } \\
\text { reciprocity }\end{array}$ & Strong-form & Strong-form & Weak-form \\
\hline
\end{tabular}


Figure 1

Investor Relations as Market-Based Assets and the Role of (the) Marketing (Function)

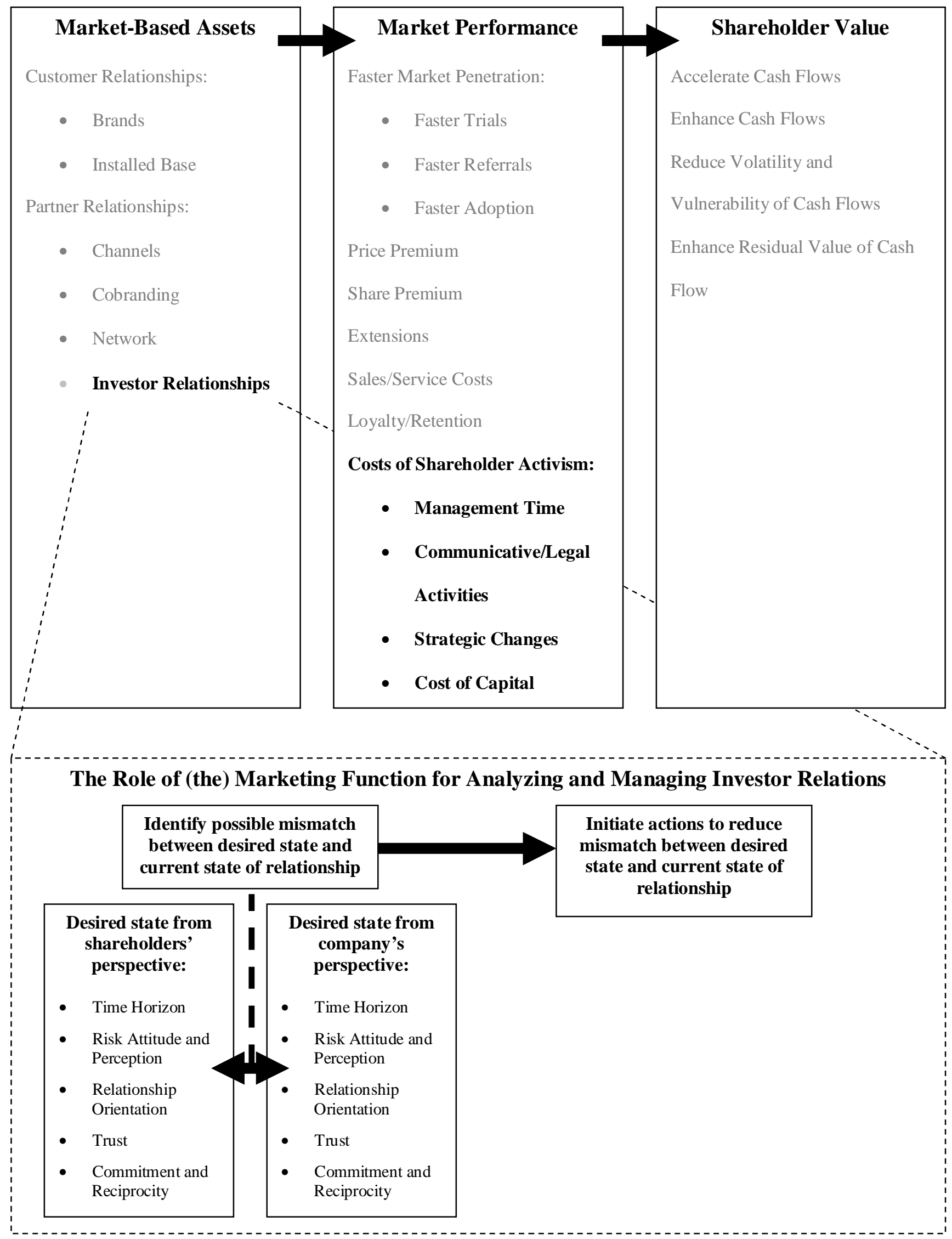


Figure 2

\section{Shareholder Activism at Blockbuster}

\section{Blockbuster}

Blockbuster is a leading global provider of in-home movie and game entertainment, with over 8,000 stores throughout the Americas, Europe, Asia, and Australia. During the last years, Blockbuster experienced a number of critical incidents of shareholder activism. Most notably, the activist investor Carl C. Icahn pushed for a special dividend of $\$ 330$ million in 2005, which the CEO at that time, John Antioco, called "nothing more than a liquidation strategy". In the proxy battle that followed, Icahn won three seats on the board of directors, of which one was taken by himself. In 2007, Antioco was replaced as CEO of Blockbuster by Jim Keyes, former president and chief executive of 7-Eleven. Under his command, Blockbuster has started several new strategic initiatives and has taken a number of decisive actions to improve the near-term profitability of the company. Stock market analysts consider Keyes to be a good choice considering his experience in implementing technology and sophisticated inventory management in convenience store operations (Forbes July $2^{\text {nd }}$ 2007). 
Figure 3

Shareholder Activism at ABN AMRO

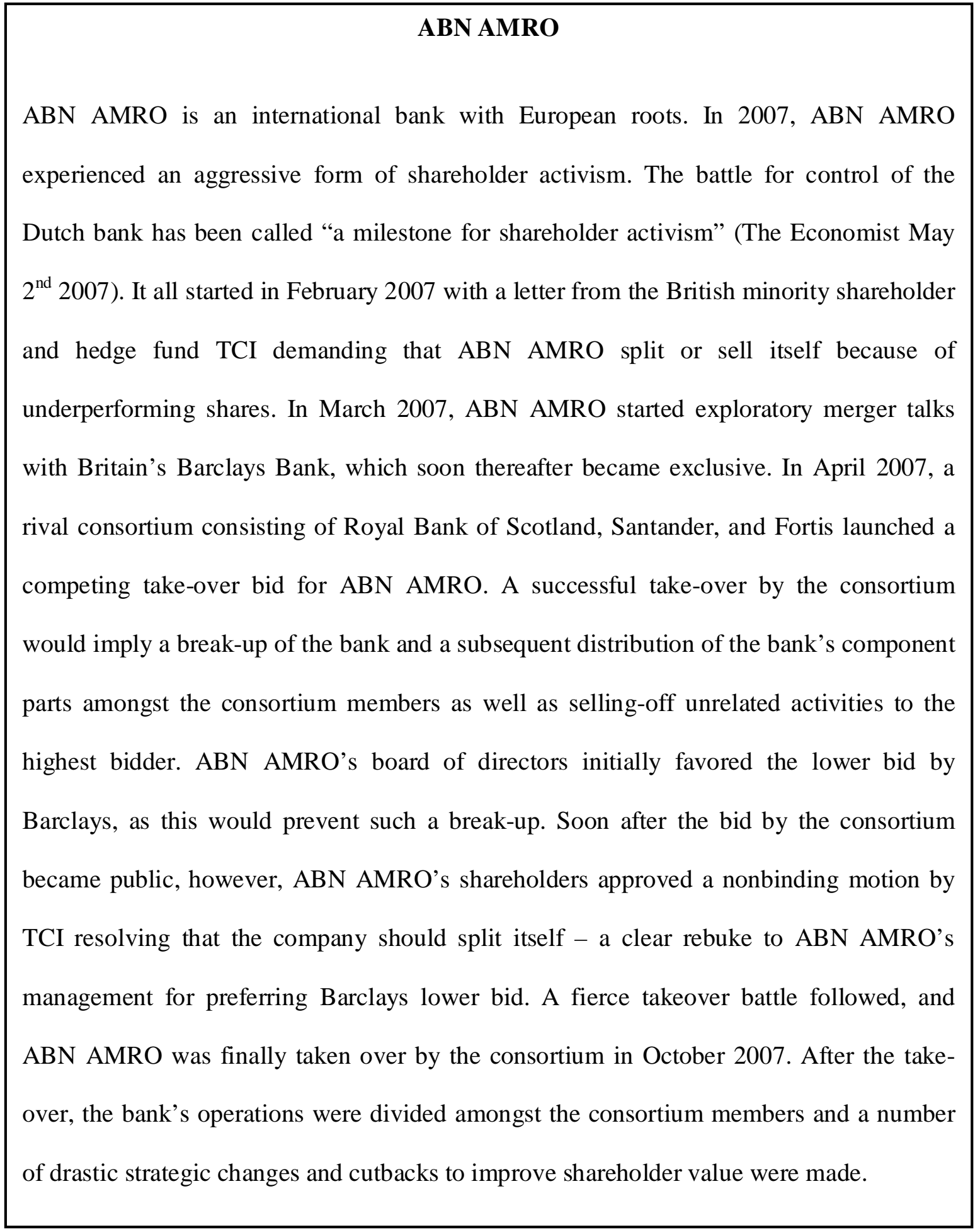


Figure 4

Shareholder Activism at Toyota

\section{Toyota}

Toyota Corporation is a multinational corporation headquartered in Japan, and one of the world's most dominant car manufacturers. Toyota owns and operates the Toyota, Lexus, and Scion brands and has a majority shareholding in Daihatsu Motors. Toyota is known for its very close and long-term relationships with a small number of large shareholders. While the average share in a public company in the US is held for about 2 years, in Japan the average holding period is 7 years, allowing a corporation to focus on their long-term strategic vision. For Toyota this means that although publicly traded, it can run its business according to the philosophy "customer first, dealer second, company third". The owners of Toyota stand right behind management to do what is right for the customers, ignoring the short-term financial effects of such a strategy, as it is believed that providing excellent value to customers will eventually also result in excellent shareholder value (see e.g., Reichheld 1996). 
Figure 5

Seven Rules for Marketing to Manage Investor Relations

For an optimal relationship between companies and investors and a minimum of shareholder activism:

1. the time horizons of both parties should be aligned,

2. the risk attitude and risk perception of both parties should be congruent,

3. the behavior of both parties should be guided by a cooperative relationship orientation,

4. both parties should evaluate their interactions using the same evaluation mode,

5. higher forms of trust by both parties in each other are necessary,

6. both parties should (a) commit to this relationship, and (b) do so to a similar extent,

7. both parties should support weak-form reciprocity. 


\section{References}

Albuquerue, R. and W. Neng (2008), "Agency Conflicts, Investment, and Asset Pricing," The Journal of Finance, 63(1), 1-40.

American Marketing Association (1948), "Report of the Definitions Committee," Journal of Marketing, 13(October), 202-10.

American Marketing Association (2007), "Report of The Definitions Committee," Journal of Marketing, 71(October).

Ang, J. S., R. A. Cole, and J. W. Lin (2000), "Agency Costs and Ownership Structure," The Journal of Finance, 55(1), 81-107.

Angle, H. and J. Perry (1981), "An Empirical Assessment of Organizational Commitment and Organizational Effectiveness," Administrative Science Quarterly, 26 1-14.

Bagozzi, R. P. (1995), "Reflections on Relationship Marketing in Consumer Markets," Journal of the Academy of Marketing Science, 23(4), 272-7.

Barney, J. (1991), "Firm Resources and Sustained Competitive Advantage," Journal of Management, 17(1), 99-120.

Barney, J., M. Wright, and D. J. Ketchen (2001), "The Resource-Based View of the Firm: Ten Years after 1991," Journal of Management, 27(6), 625-41.

Berman, S. L., A. C. Wicks, S. Kotha, and T. M. Jones (1999), "Does Stakeholder Orientation Matter? The Relationship Between Stakeholder Management Models and Firm Financial Performance," Academy of Management Journal, 42(5), 488-506.

Berry, L. and A. Parasuraman (1993), "Building a New Academic Field - The Case of Services Marketing," Journal of Retailing, 1 13-60. 
Borden, N. H. (1964), "The Concept of the Marketing Mix," Journal of Advertising Research, June 2-7.

Brisley, N. (2006), "Executive Stock Options: Early Exercise Provisions and Risk-Taking Incentives," The Journal of Finance, 61(5), 2487-509.

Carpenter, j. N. (2000), "Does Option Compensation Increase Managerial Risk Appetite?," The Journal of Finance, 55(5), 2311-31.

Chaney, P., T. Devinney, and R. Winer (1991), "The Impact of New Product Introductions on the Market Valuation of Firms," Journal of Business, 64(4), 573-610.

Conchar, M. P., G. M. Zinkhan, C. Peters, and S. Olavarrieta (2004), "An Integrated Framework for the Conceptualization of Consumers' Perceived-Risk Processing," Journal of the Academy of Marketing Science, 32(4), 418-36.

Cox, D. F. (1967), Risk Taking and Information Handling in Consumer Behavior. Boston: Graduate School of Business Administration, Harvard University.

Cox, D. F. and S. U. Rich (1964), "Perceived Risk and Consumer Decision-Making: The Case of the Telephone Shopping," Journal of Marketing Research, 1(4), 32-9.

Day, G. and L. Fahey (1988), "Valuing Market Strategies," Journal of Marketing, 52(July), 4557.

Deutsch, M. (1982), "Interdependence and Psychological Orientation," in Cooperation and Helping Behavior: Theories and Research, V. J. Derlega and J. L. Grzelak, eds. New York: Academic Press, 15-42.

Dewenter, K. L. and V. A. Warther (1998), "Dividens, Asymmetric Information, and Agency Conflicts: Evidence from a Comaprison of the Dividend Policies of Japanese and U.S. Firms," The Journal of Finance, 53(3), 879-905. 
Dolphin, R. R. (2004), "The Strategic Role of Investor Relations," Corporate Communications: An International Journal, 9(1), 25-42.

Dwyer, R. F., P. H. Schurr, and S. Oh (1987), "Developing Buyer-Seller Relationships," Journal of Marketing, 51(April), 11-27.

Easley, D. and M. O'Hara (2004), "Information and the Cost of Capital," The Journal of Finance, $59(4), 1553-83$

Eisenhardt, K. M. and M. J. Zbaracki (1992), "Strategic Decision Making," Strategic Management Journal, 13(Winter), 17-37.

Fisher, K. L. and M. Statman (1999), "A Behavioral Framework for Time Diversification," Financial Analysts Journal, 55(May/June), 88-97.

Fisk, R., S. Brown, and M. Bitner (1993), "Tracking the Evolution of the Services Marketing Literature," Journal of Retailing, 1 61-103.

Frederick, S., G. Loewenstein, and T. O'Donoghue (2002), "Time Discounting and Time Preference: A Critical Review," Journal of Economic Literature, 40(June), 351-401.

Gillan, S. L. and L. T. Starks (1998), "A Survey of Shareholder Activism: Motivation and Empirical Evidence," Contemporary Finance Digest, 2(3), 10-34.

Glynn, W. and U. Lehtinen (1995), "The Concept of Exchange: Interactive Approaches in Services Marketing," in Understanding Services Management. Integrating Marketing, Organisational Behaviour, Operations, and Human Resource Management, W. Glynn and J. Barnes, eds. Chichester: Wiley \& Sons, 89-118.

Gundlach, G. T., R. S. Achrol, and J. T. Mentzer (1995), "The Structure of Commitment in Exchange," Journal of Marketing, 59(January), 78-92. 
Hall, R. H. (1993), "A Framework Linking Intangible Resources and Capabilities to Sustainable Competitive Advantage," Strategic Management Journal, 14 607-18.

Hirschman, A. (1971), Exit, Voice, and Loyalty: Responses to Decline in Firms, Organizations, and States. Cambridge, MA: Harvard University Press.

Hosseini, J. C. and S. N. Brenner (1992), "The Stakeholder Theory of the Firm: A Methodology to Generate Value Matrix Weights," Business Ethics Quarterly, 2(2), 99-119.

Hyde, P., E. Landry, and A. Tipping (2004), "Making the Perfect Marketer," Strategy+Business, 37(Winter), 37-43.

Jensen, M. C. and W. H. Meckling (1976), "Theory of the Firm: Managerial Behavior, Agency Costs and Capital Structure," Journal of Financial Economics, 3 305-60.

Jensen, M. C. and R. S. Ruback (1983), "The Market for Corporate Control: The Scientific Evidence," Journal of Financial Economics, 11(April), 5-50.

Joshi, A. and D. M. Hanssens (2007), "Advertising Spending, Competition and Stock Return,". Joshi, A. and D. M. Hanssens (2008), "Movie Advertising and the Stock Market Valuation of Studios: A Case of "Great Expectations"?," Marketing Science, forthcoming.

Kanter, R. M. (1972), Commitment and Community. Cambridge, MA: Harvard University Press. Klos, A., E. U. Weber, and M. Weber (2005), "Investment Decisions and Time Horizon: Risk Perception and Risk Behavior in Repeated Gambles," Management Science, 51(12), 1777-90.

Knight, F. H. (1921), Risk, Uncertainty and Profit. Boston, MA : Hart, Schaffner \& Marx; Houghton Mifflin Company.

Kriger, M. P. and L. B. Barnes (1992), "Organizational Decision Making as Hierarchical Levels of Drama," Journal of Management Studies, 27(4), 363-75. 
Lehmann, D. R. (2004), "Linking Marketing to Financial Performance and Firm Value," Journal of Marketing, 68(October), 73-5.

Lehmann, D. R., P. Berger, N. Edchambadi, M. George, R. Rizley, and R. Vanketasan (2006), "From Customer Lifetime Value to Shareholder Value," Journal of Service Research, $9(2), 156-67$.

Lehmann, D. R. and S. Gupta (2006), "The Impact of CLV on Firm Valuation," Journal of Relationship Marketing, 5(2), 87-110.

Leland, H. E. (1998), "Agency Cost, Risk Management and Capital Structure," The Journal of Finance, 53(4), 1213-44.

Lewicki, R. J. and B. B. Bunker (1995), "Trust in Relationships: A Model of Development and Decline," in Conflict, Cooperation, and Justice: Essays Inspired by the Work of Morton Deutsch, B. B. Bunker and J. Z. Rubin, eds. San Fransisco: Jossey-Bass, 133-74.

Lovett, M. J. and J. B. MacDonald (2005), "How Does Financial Performance Affect Marketing? Studying the Marketing-Finance Relationship from a Dynamic Perspective," Journal of the Academy of Marketing Science, 33(4), 476-85.

Marston, C. and M. Straker (2001), "Investor Relations: a European Survey," Corporate Communications: An International Journal, 6(2), 82-93.

Mauer, D. C. and A. J. Triantis (1994), "Interactions of Corporate Financing and Investment Decisions: A Dynamic Framework," The Journal of Finance, 49(4), 1253-77.

Mayer, R. C., J. H. Davis, and F. D. Schoorman (1995), "An Integrative Model of Organizational Trust," Academy of Management Review, 20(3), 709-34.

Meeker, B. F. (1983), "Cooperative Orientation, Trust, and Reciprocity," Human Relations, $37(3), 225-43$. 
Mintzberg, H. (1979), The Structuring of Organizations. Englewood Cliffs: Prentice-Hall.

Mitchell, R. K., B. R. Agle, and D. J. Wood (1997), "Toward a Theory of Stakeholder Identification and Salience: Defining the Principle of Who and What Really Counts," Academy of Management Review, 22(4), 853-86.

Moorman, C. and R. T. Rust (1999), "The Role of Marketing," Journal of Marketing, 63(Special Issue), 180-97.

Moorman, C., G. Zaltman, and R. Deshpande (1992), "Relationships Between Providers and Users of Market Research: The Dynamics of Trust Within and Between Organizations," Journal of Marketing Research, 29(3), 314-28.

Morgan, R. M. and S. D. Hunt (1994), "The Commitment-Trust Theory of Relationship Marketing," Journal of Marketing, 58(July), 20-38.

Mowday, R., L. Porter, and R. Steers (1982), Organizational Linkages: The Psychology of Commitment, Absenteeism, and Turnover. New York: Academic Press.

Nath, P. and V. Mahajan (2008), "Chief Marketing Officers: A Study of Their Presence in Firms' Top Management Teams," Journal of Marketing, 72(January), 65-81.

O'Donoghue, T. and M. Rabin (1999), "Doing It Now or Later," American Economic Review, 89(1), 103-24.

Pennings, J. M. E. (2004), "A Marketing-Finance Approach towards Industrial Channel Contract Relationships: a Model and Application," Journal of Business Research, 57(6), 601-9.

Pennings, J. M. E., O. Isengilda-Massa, S. H. Irwin, P. Garcia, and D. L. Good (2008), "Producers' Complex Risk Management Choices," Agribusiness, 24(1), 31-54.

Pennings, J. M. E. and A. Smidts (2000), "Assessing the Construct Validity of Risk Attitude," Management Science, 46(10), 1337-48. 
Pennings, J. M. E. and B. Wansink (2004), "Channel Contract Behavior: The Role of Risk Attitudes, Risk Perceptions, And Channel Members' Market Structures," Journal of Business, 77(4), 697-723.

Pennings, J. M. E., B. Wansink, and M. T. G. Meulenberg (2002), "A Note on Modeling Consumer Reactions to a Crisis: The Case of the Mad Cow Disease," International Journal of Research in Marketing, 19(1), 91-100.

Polonsky, M. J., S. Schuppisser, and S. Beldona (2002), "A Stakeholder perspective for Analyzing Marketing Relationships," Journal of Market-Focused Management, 5 109-26.

Raju, J. S. (2005), "Revitalizing the Role of Marketing in Business Organizations: What Can Poor Academics Do to Help?," Journal of Marketing, 69(October), 17-9.

Rao, H. and K. Sivakumar (1999), "Institutional Sources of Boundary-Spanning Structures: The Establishment of Investor Relations Departments in the Fortune 500 Industrials," Organization Science, 10(1), 27-42.

Rao, R. K. S. and N. Bharadwaj (2008), "Marketing Initiatives, Expected Cash Flows, and Shareholders' Wealth," Journal of Marketing, 72(January), 16-26.

Read, D., G. Loewenstein, and M. Rabin (1999), "Choice Bracketing," Journal of Risk and Uncertainty, 19(1-3), 171-97.

Reichheld, F. F. (1996), The Loyalty Effect: The Hidden Force Behind Growth, Profits and Lasting Value. Boston/Massachusetts: Harvard Business School Press.

Rust, R. T., K. N. Lemon, and V. A. Zeithaml (2004), "Return on Marketing: Using Customer Equity to Focus Marketing Strategy," Journal of Marketing, 68(1), 109-27.

Rust, R. T., A. Zahorik, and T. Keiningham (1995), "Return of Quality (ROQ): Making Service Quality Financially Accountable," Journal of Marketing, 59(April), 58-70. 
Savage, G. T., T. W. Nix, C. J. Whitehead, and J. D. Blair (1991), "Strategies for Assessing and Managing Organizational Stakeholders," Academy of Management Executive, 5(2), 61 75.

Shapira, Z. (2002), Organizational Decision Making. New York: Cambridge University Press.

Shefrin, H. and M. Statman (2000), "Behavioral Portfolio Theory," The Journal of Financial and Quantitative Analysis, 35(2), 127-51.

Srinivasan, R. and C. Moorman (2005), "Strategic Firm Commitments and Rewards for Customer Relationship Management in Online Retailing," Journal of Marketing, 69(October), 193-200.

Srinivasan, S. and D. M. Hanssens (2007), "Marketing and Firm Value,".

Srinivasan, S., K. Pauwels, J. Silva-Risso, and D. M. Hanssens (2007), "Product Innovations, Advertising and Stock Returns,".

Srivastava, R. K., L. Fahey, and H. K. Christensen (2001), "The Resource-Based View and Marketing: The Role of Market-Based Assets in Gaining Competitive Advantage," Journal of Management, 27(6), 777-802.

Srivastava, R. K., T. A. Shervani, and L. Fahey (1997), "Driving Shareholder Value: The Role of Marketing in Reducing Vulnerability and Volatility of Cash Flows," Journal of MarketFocused Management, 2(1), 49-64.

Srivastava, R. K., T. A. Shervani, and L. Fahey (1998), "Market-Based Assets and Shareholder Value: A Framework for Analysis," Journal of Marketing, 62(January), 2-18.

Statman, M. (1999), "Behavioral finance: Past Battles and Future Engagements," Financial Analysts Journal, 55(6), 18-27. 
Thaler, R. H. (1985), "Mental Accounting and Consumer Choice," Marketing Science, 4(3), 199214.

Thaler, R. H. (2000), "Mental Accounting Matters," in Choices, Values, and Frames, D. Kahneman and A. Tversky, eds. New York: Cambridge University Press, 241-68. Tuominen, P. (1997), "Investor Relations: A Nordic School Approach," Corporate Communications: An International Journal, 2(1), 46-55.

Turnbull, S. M. (1979), "Debt Capacity," The Journal of Finance, 34(4), 931-40.

Vargo, S. L. and R. F. Lusch (2004), "Evolving to a New Dominant Logic for Marketing," Journal of Marketing, 68(January), 1-17.

Vargo, S. L. and R. F. Lusch (2008), "Service-Dominant Logic: Continuing the Evolution," Journal of the Academy of Marketing Science, 36(1), 1-10.

Webster, F. E. (1992), "The Changing Role of Marketing in the Corporation," Journal of Marketing, 56(October), 1-17.

Webster, F. E. (2005), "Back to the Future: Integrating Marketing as Tactics, Strategy, and Organizational Culture," Journal of Marketing, 69(October), 4-6.

Webster, F. E., A. J. Malter, and S. Ganesan (2003), "Can Marketing Regain a Seat at the Table?," Cambridge, MA: Marketing Science Institute, 29-49.

Zorn, D. M. (2004), "Here a Chief, There a Chief: The Rise of the CFO in the American Firm," American Sociological Review, 69(June), 345-64. 